\title{
The 4-0-8 Sheffield Fund
}

In 2001 the 4-0-8 Young People's Consultation Centre Ltd, Sheffield, UK made a significant donation to the Faculty of Family Planning and Reproductive Health Care (FFPRHC) for the purpose of funding training for health care professionals who had limited funding for attending training meetings. Any person working in the field of reproductive and sexual health care within the UK may apply. Approximately £1000 will be allocated every 3 months, either as a single award or divided between the successful applicants.

For details on how to apply to the 4-0-8 Sheffield Fund visit the Faculty website at www.ffprhc.org.uk. For an application form apply to: Chair of the Education Committee, Faculty of Family Planning and Reproductive Health Care of the RCOG, 27 Sussex Place, Regent's Park, London NW1 4RG, UK. Closing date: 6 months prior to the event for which funding is applied for.

\section{The David Bromham Annual Memorial Award DYNAMIC DOCTORS DESERVE RECOGNITION}

David Bromham was the first Chairman of The Faculty of Family Planning and Reproductive Health Care. Sadly, halfway through his second term of office he became ill and in 1996 he died. His loss was tragic, not only for the Faculty, but for the family planning movement in Britain and worldwide.

Through his life David was an energetic and inspirational man. Whilst in Leeds he set up an assisted conception programme, which was and is one of the most successful in the world. In 1991 he set up a fertility control unit designed to provide a more accessible service for the termination of pregnancy. He also carried out an extensive programme of research and was closely involved with the British Journal of Family Planning (now the Journal of Family Planning and Reproductive Health Care).

\section{The David Bromham Memorial Award}

David Bromham would have said: 'Just do it! You have an idea? Follow it up. Keep it simple, don't worry if it fails. Any and every effort aids progress.' Although David was a man of action he also knew how difficult it is to make time to further a project in the middle of a busy life. Dynamic doctors therefore deserve recognition.

\section{Award Criteria}

The David Bromham Memorial Award is in remembrance of a man who was happiest when deeply immersed in all that was happening within his fields of interest and who never wasted any time.

The Award is not intended to be a prize for a long and distinguished service, rather for a piece of work which through inspiration, innovation or energy has furthered the practice of family planning and reproductive health care in any way and any setting. It is not a research grant. Younger health professionals sometimes undervalue their achievements but they are exactly the people that David Bromham would have wished to see encouraged as this award now acknowledges.

\section{Nominations}

The award will be made either to an individual (who must be a current Diplomate or Member of the Faculty) or to a team, which could be multidisciplinary. In the latter case the lead doctor should be a current member of the Faculty. You may nominate yourself or your team or be nominated by someone else.

\section{Award}

The award itself, which will be presented at each year's AGM, will comprise a monetary sum and inscribed memento.

\section{Sponsors}

The award is sponsored by the Pharmaceutical Contraceptive Group and its member companies: Hoechst Marion Roussel, Janssen-Cilag, Organon Laboratories, Pharmacia \& Upjohn, Schering Health Care and Wyeth Laboratories, with contributions from the members of the Faculty, affiliated groups and other organisations with which David had links.

\section{Nomination Process}

Nomination is by completion of a form that can be downloaded from the Faculty website at www.ffprhc.org.uk. Completed submissions must be received at the Faculty office by 10 April annually.

\section{The Janssen-Cilag Travelling Scholarship}

This scholarship, established in memory of Dr Ann Horler, continues to be sponsored by Janssen-Cilag. The purpose of the scholarship is to enable the successful candidate to travel to any country, subject to approval by the selection committee, in order to gain experience that will be applicable to his or her daily work. Those eligible to apply are Diplomates and Members of the Faculty of Family Planning and Reproductive Health Care of the Royal College of Obstetricians and Gynaecologists, who are based in the British Isles and currently working in family planning.

Once the successful scholar is announced at the AGM usually held in May, Janssen-Cilag will arrange presentation of the sponsorship, the value of which has increased to $\mathbf{2 2 5 0 0}$, enabling the scholar to make his or her own travelling arrangements. It is expected that the successful candidate will travel before March of the following year and give a report to the annual symposium of the Faculty in that year. This report may be published at a later date in the Journal of Family Planning and Reproductive Health Care. Those wishing to apply for the scholarship are asked to submit a typewritten summary of the proposed project, to include:

- Details of the places, organisations and individuals to be visited, with dates;

- Aims, objectives, benefits and how the experience will assist them in their daily work on their return; and

- A brief curriculum vitae with details of their current post.

Applications should be signed and dated, and returned to the Secretary, Faculty of Family Planning and Reproductive Health Care, RCOG, 27 Sussex Place, Regent's Park, London NW1 4RG, UK by 7 April annually. 